УДК 633.68:631.421

(C) 2012

Бондус Р. О., кандидат сільськогосподарських наук

Устимівська дослідна станція рослинництва Інституту рослинництва ім. В. Я. Юр'єва НААН

\title{
ГЕНЕТИЧНІ РЕСУРСИ КАРТОПЛІ НА УСТИМІВСЬКІЙ ДОСЛІДНІЙ СТАНЦІї РОСЛИННИЦТВА
}

\section{Рецензент - доктор сільськогосподарських наук, професор П. В. Писаренко}

\begin{abstract}
Наведено результати досліджень із формування та ведення колекиії картоплі на Устимівській дослідній станиії рослинництва (південна частина Лісостепу України), щзо нараховує 615 зразків із більше ніж 30-ти країн. Представлено головні напрями роботи, иінність і важливість формування, поповнення та збереження генофонду картоплі. Розкрито аспекти пошуку джерел господарсько цінних ознак. Проведено роботу із залучення й вивчення інтродукованого матеріалу, сформовано 4 ознакові колекиії, виділено зразки з иінними агрономічними ознаками, які передано до наукових установ Украӥни для подальшого включення в селекиійні програми по картоплі. Використання джерел господарсько иінних ознак, виділених із колекиіі генофонду картоплі, дає змогу створювати новий цінний вихідний матеріал для селекциї.
\end{abstract}

Ключові слова: картопля, генетичні ресурси, інтродукиія, сорти, родовід, колекиія, збереження.

Постановка проблеми. Свого часу М. І. Вавилов створив і розвинув вчення про вихідний матеріал. На базі експедиційних зборів у багатьох країнах світу і теоретичних узагальнень ним була розгорнута широка інтродукційна робота з метою мобілізації рослинних ресурсів світу для окультурення й подальшої селекційної роботи [2]. Пріоритет у створенні колекції різних культур, у тому числі й картоплі, належить M. I. Вавилову. Безпосередньо за його участі та вчених С. М. Букасова, С.В.Юзепчука, П. М. Жуковського були проведені експедиції на батьківщину картоплі - в Південну Америку (1925, 1927, 1932, 1955, 1958 рр). Це допомогло виявити значне різноманіття картоплі та зібрати матеріал для колекції цієї культури. Колекція - це систематизоване зібрання видів (species), підвидів (subspecies), груп різновидностей (convarietas), різновидностей (varietas), форм (forma), зразків і сортозразків (concultivar), сортів (cultivar) та гібридів (hybrids) картоплі, залучених із різних країн світу, що має на меті збереження генофонду [3].

Аналіз основних досліджень і публікацій, у яких започатковано розв'язання проблеми. Необхідність збору й збереження зразків генофон- ду рослин для нинішнього та майбутніх поколінь обумовлена тим, що внаслідок розвитку науковотехнічного прогресу на величезних площах сільськогосподарських угідь велике різноманіття сортів заміняються одним сортом або декількома, які на даний час вважаються найурожайнішими, тобто зростає генетична однорідність посівів і плантацій. Іде також звуження видового різноманіття культурних рослин: триває вирощування лише тих, що забезпечують найбільший на даний час прибуток. Як показав трагічний досвід людства, ця ситуація періодично ставить під загрозу сільське господарство в цілому, тобто добробут і саме існування населення, поскільки при цьому дестабілізується виробництво, зростає ушкоджуваність посівів і плантацій шкідниками та хворобами, погодними чинниками, кліматичними змінами. Класичним прикладами $є$ епіфітотія фітофторозу картоплі у північній Європі у 40-х роках XIX ст., коли від голоду загинула третина населення Ірландії [12].

Біологічні особливості картоплі характеризуються домінуванням вегетативного способу розмноження, що пов'язано з ураженістю численними збудниками хвороб та шкідниками, 3 їх внутрішньовидовою специфікою. Крім того, співродичі культурних сортів даної культури здебільшого ростуть в умовах, що суттєво відрізняються від природно-кліматичних і географічних аналогів територій генцентрів їх походження. Тому зрозуміло, чому збереження колекції картоплі $є$ кропіткою роботою. Надзвичайно важливим є питання збереження генофонду картоплі [9].

Цінність і особливість культури картоплі полягає в іiі генетичному потенціалі, представленому 230 видами, серед яких $є$ можливість виділити гени 3 ефективним контролем практично всіх ознак, якими повинен характеризуватися сорт і які відсутні у S. Tuberosum L. [10]. У зв'язку з цим стратегічне й соціально-економічне значення генетичних ресурсів картоплі з роками збільшується, що дає нові можливості прискореними темпами використовувати їх для одержання кон- 
курентноспроможної продукції та стабільного розвитку галузі, а відтак $є$ складовою продовольчої безпеки країни [11].

Метою досліджень $\epsilon$ формування, підтримання, збереження й вивчення колекції картоплі. Виділення джерел господарсько цінних ознак, сортів-еталонів, створення ознакових колекцій для використання в селекційній практиці та інших наукових і освітніх програмах.

Методика досліджень. Сповна використати генетичне різноманіття картоплі можна лише на базі всебічного вивчення за комплексом господарсько цінних ознак. Вивчення проводиться як польовими, так і спеціальними методами за урожайністю, ознаками продуктивності та ії елементами, жаро- й посухостійкості, стійкості до хвороб і шкідників, показниками якості продукції [4, 6-8].

Результати досліджень. Реалізація розробок М. І. Вавилова здійснювалась у масштабі всієї країни. У 1954 році Устимівська дослідна станція рослинництва (УДСР) підпорядковується Всесоюзному інституту рослинництва ім. М. І. Вавилова (ВIP). Продовжуючи його ідею, на дослідній станції проводиться робота 3 генетичними ресурсами рослин, у тому числі й картоплі.

Після здобуття Україною незалежності дослідна станція 31992 року входить до Системи генетичних ресурсів рослин України і є виконавцем державної науково-технічної програми «Генетичні ресурси рослин». У рамках даної програми поряд 3 іншими культурами продовжувалася робота 3 формування, підтримання, поповнення та вивчення колекції картоплі, яку було започатковано ще у 50-х роках минулого століття. Змінювалися назва й підпорядкування станції, проте завжди залишалося головне іï завдання: збереження генетичних ресурсів рослин [13].

Головними напрямами роботи Устимівської ДСР є залучення нових зразків та їх карантинна перевірка, збереження колекційного матеріалу в живому стані з високою життєздатністю і сортовою чистотою, всебічне вивчення колекцій різних культур, виділення джерел і донорів господарсько цінних ознак, розмноження для закладки на середньострокове зберігання в Національне сховище й сховище дослідної станції, забезпечення селекційних установ України та інших країн цінним вихідним матеріалом й інформацією про нього.

Нині сформована колекція має на меті збереження генофонду картоплі в колекції ex situ створення банків насіння, меристем та інших тканин in vitro, пилку, ДНК, а для рослин, що розмножуються вегетативно, - колекційних садів, плантацій («польових генбанків») [9]. Різноманіття колекції картоплі представлено зразками і сортозразками (concultivar) більше ніж із 30-ти країн близького та далекого зарубіжжя. Найвищий відсоток кількості сортозразків представлено з України та Німеччини (по 23,0 \%), із Нідерландів - 14,3\%, дещо менше з Росії - 8,4 \%, Білорусі - 6,7 \%, Польщі - 4,6 \%, Чехії - 3,0 \% та інших країн.

Кожен зразок колекції картоплі Устимівської ДСР $є$ одиницею генофонду, що знаходиться на збереженні й занесений до Національного каталогу генетичних ресурсів рослин України. Вітчизняний і світовий досвід довів, що для збереження генофонду культурних рослин найбільш надійним $€$ створення банків генетичних ресурсів рослин (генбанків) [17]. Генбанк забезпечує найбільшу доступність зразків генофонду для використання у селекційних, наукових, освітніх та інших програмах, із метою швидкого вирішення завдань, що виникають у будь-який момент. Генбанк - це база для залучення (інтродукції) нових цінних сортів і форм, розширення генетичного різноманіття культурних і дикорослих рослин [12]. На весь об'єм колекції картоплі в кількості 615 зразків сформована паспортна база даних у комп'ютерній інформаційній системі (IC) «Генофонд рослин», створеній Національним центром генетичних ресурсів рослин України (НЦГРРУ). Електронна версія паспортної бази даних містить інформацію про цінність зразка, його походження, назву оригінатора, дані про автора (авторів), доступність матеріалу, родовід, біологічний статус, місце збору чи шлях отримання та багато інших цінних даних.

За результатами вивчення генофонду картоплі щорічно виділяються джерела та донори господарсько цінних ознак, які передаються користувачам для включення у селекційні, наукові, освітні та інші програми [13-16]. У результаті проведеної роботи сформовано 4 ознакові колекції картоплі, в яких зразки підібрані за певним рівнем фенотипового прояву окремих ознак або їх поєднань:

- ознакова колекція за урожайністю, що включає 46 зразків із восьми країн світу;

- ознакова колекція за вмістом крохмалю й технологічними властивостями, що включає 61 зразок із п'яти країн світу;

- робоча ознакова колекція за великобульбовістю, що включає 121 - із 16 країн світу;

- робоча ознакова колекція за стійкістю до вірусних хвороб, що включає 34 зразки 3 десяти країн світу. 
До цих колекцій включено зразки з різним рівнем прояву ознак згідно з міжнародним класифікатором [5]. Неодмінними елементами ознакової колекції $є$ еталонні зразки, які мають більш стабільний рівень прояву ознак при можливо вищому рівні продукційного процесу. Ознакові колекції $\epsilon$ першим кроком до створення генетичних колекцій [12].

У результаті проведеної роботи виділено і зареєстровано в Національному центрі генетичних ресурсів рослин України 8 цінних зразків картоплі: сорт Петровська (Росія) - надраннє формування товарного врожаю ( $<40$ днів після посадки); Зарево (Україна) - сорт-еталон за високим вмістом крохмалю в бульбах (27,0\%); Явір (Україна) - висока стійкість до фітофторозу (9 балів за 9-бальною шкалою стійкості); Фантазія (Україна) - поєднання багатобульбовості (14 шт. товарних бульб на кущ) із підвищеним вмістом крохмалю $(18,5 \%)$ і хорошими смаковими якостями; Тирас (Україна) - раннє формування товарного врожаю (<40 днів) після посадки, висока врожайність і товарність; Світанок київський (Україна) - високі смакові якості, підвищений вміст крохмалю $(20,0$ \%); Оберіг (Україна) - висока продуктивність (900 г/кущ), товарність (90,0 \%), великобульбовість (100 г); Багряна (Україна) - висока стійкість до фітофторозу (9 балів за 9-бальною шкалою стійкості) та високі смакові якості; Незабудка (Україна) - стійкий проти вірусного скручення листків (збудник віpyc-L).

Значне генетичне різноманіття представляють старі й сучасні селекційні сорти картоплі багатьох країн світу. Певну генетичну цінність мають сорти-«ветерани», створені понад 80-100 років тому. Деякі 3 них до цього часу вирощуються у різних країнах і використовуються в селекційних програмах. Їх довговічність обумовлена високою продуктивністю, скоростиглістю, польовою стійкістю до вірусних хвороб. Кожен із цих сортів брав участь у створенні десятків і сотень нових, які вирощувались або вирощуються в даний час. У селекції їх використовують в якості генетичних джерел і донорів таких ознак, як висока продуктивність, крохмалистість, скоростиглість, стійкість до вірусів [1].

Колекція Устимівської дослідної станції рослинництва нараховує цілу низку таких зразків: Aquilla, Schwalbe, Apta, Ella, Achat, Saba, Runo, Adretta (Німеччина); Maris Squire (Великобританія); Beko, Belinda (Австрія); Veto (Фінляндія); Перлина, Чарівниця, Немішаєвська біла (Україна), Kufri Zqoti (Індія), Buesa (Іспанія), Петро- вська, Іскра (Росія) та ін.

Сорт Aquilla не відзначається стійкістю до парші звичайної, але стійкий до раку, фітофторозу, вірусних хвороб і добре передає ці ознаки своїм нащадкам. Його нащадками є 52 сорти, більшість із яких - ракостійкі, є також стійкі до фітофторозу (Ancilla, Datura, Drossel, Fink, Horsa, Star, Susana, Teho, Zeising, Кандадат, Огонек); до вірусних хворб: Amsel (відносно стійкий до вірусів L та Y), Drossel (стійкий до Y і зморшкуватої мозаїки), Fink (стійкий до вірусу L, надчутливий до X), Schwalbe (стійкий до вірусів L, Y), Star (стійкий до L і мозаїчних вірусів), Zeisig (стійкий до L, надчутливий до $\mathrm{X}$ ).

Чимало нащадків сорту Schwalbe (24 сорти). 3-поміж них значна кількість стійких до вірусних хвороб або таких, що слабо пошкоджуються ними: Adretta, Binova, Galina, Lardia, Karsa, Mariella, Specula, Turbella, Xenia та ін. Сорти, створені на основі вищезгаданого зразка Schwalbe, є подібними за морфологічними ознаками й увійшли в сортотип Adretta: Adretta = (Apta x Stamm x Schwalbe) x (Axilia x Stamm); Binova $=$ Bintje $\mathrm{x}$ Schwalbe; Elgina $=($ Saskia $\mathrm{xSchwalbe}) \mathrm{x}($ Apta $\mathrm{x}$ Stamm $) ;$ Kardia $=[($ Stamm $\mathrm{x}$ Apta) x Ora ] x Schwalbelibelle; Mariella $=$ Eva $\mathrm{x}$ Schwalbe.

Багаточисельне потомство сорту Apta (13 copтів). Сорт Ora, створений на основі сорту Capella, використовувався в створенні високопродуктивних сортів - Antares, Galina, Leander, Turbella, Темп та ін. [17].

Сорт Петровська було отримано з Мурманської дослідної станції й включено до колекції у 1956 році. За більше ніж півстоліття вирощування без сортооновлення в умовах південної частини Лісостепу України він не втратив своєї головної цінності - надраннього накопичення товарного врожаю, що доводить його високий ефективний генетичний контроль стійкості до виродження, пластичності та продуктивності. Це стосується й сорту Romano (Нідерланди), який відзначається великобульбовістю й надзвичайно тривалим періодом спокою. Завдяки цим цінним ознакам сорт зміг заповнити ринок картоплі на Полтавщині, міцно утримуючись на ньому досить тривалий час. Поряд із старими сортами колекція весь час поповнюється новими селекційними сортами: Innovator (Нідерланди), який має великий попит у ресторанах «МакДональдс», i сорт Nicola (Нідерланди), який у цій країні вважається одним 3 основних столових сортів і займає 50 \% ринку, при тому, що у Нiдерландах вирощується 250 сортів картоплі. 
Надзвичайною пластичністю відзначаються сорти Слов'янка (Україна), Sante (Нідерланди), що мають стабільно високу продуктивність незалежно від погодних умов і грунтово-кліматичної зони вирощування в Україні, що пояснюється ефективним генетичним контролем продуктивності.

Щорічно колекція картоплі Устимівської ДСР поповнюється новими зразками шляхом наукового обміну та експедиційних зборів. Пошук і збір генетичного різноманіття культурних рослин та їх дикоростучих співродичів - вихідного матеріалу продуктивності та якості, високої стійкості проти екстремальних умов зовнішнього середовища - актуальне завдання збереження генофонду в колекціях ex situ. Наукові співробітники дослідної станції систематично беруть участь у міжнародних експедиціях під головуванням Всеросійського НДІР ім. М. І. Вавилова та Національним центром генетичних ресурсів рослин України по обстеженню та збору генетичних ресурсів рослин в усіх грунтово-кліматичних зонах України й території Російської Федерації (Республіка Башкортостан, Республіка Карелія, Південний і Центральний Урал та ін.) Грунтовокліматичні умови різних природних зон позитивно впливають на формотворчі процеси рослин. У результаті експедицій проводиться збір зразків різних культур, у тому числі й картоплі. Поповнення колекції картоплі відбувається також шляхом інтродукціїі зразків із країн даленого зарубіжжя: з Канади, м. Саскатун - Russian Blue, Banana, Caribe, Norland; 3 Туреччини 2 сортозразки - Ізмір форма 1, Ізмір форма 2. Шляхом наукового збору інтродуковано Місцевий сорт картоплі із Татарстану, Місцеву Жовту - із Закарпатської області (м. Мукачеве), місцевий сорт Сибірячка - із Тюменської області, Росія. Сорт Кримська Роза було зібрано в АР Крим, м. Алу-

\section{БІБЛІОГРАФІЯ}

1. Будин К. 3. Генетические основы селекции картофеля / К. З. Будин - Л. : Агропромиздат, 1986. - $192 \mathrm{c}$.

2. Вавилов Н. И. Интродукция растений в советское время и ее результаты // Вавилов Н. И. Избранные труды: в 5-ти т. - Л., 1965. - Т. 5. C. 674-689.

3. Картопля - другий хліб: Наук.-попул. альм. для селян у трьох вип. / Упоряд. та заг. ред. П. С. Теслюка. - К. : Довіра, 1995. - Вип. I $281 \mathrm{c}$.

4. Литвинов Л. С. Диагностика устойчивости растений к стрессовым воздействиям. Методи- шта, с. Сонячногірське та багато інших. Крім того колекція картоплі дослідної станції поповнюється новими перспективними селекційними сортами шляхом наукового обміну з Інститутом картоплярства НААН України та іншими науково-дослідними установами.

Висновки. У результаті залучення до колекції нових зразків і вивчення даного інтродукованого матеріалу сформовано ознакові колекції, виділено цінні зразки, джерела господарсько цінних ознак, які передаються для подальшого включення в селекційні та наукові програми по картоплі: Інституту картоплярства НААН України (відділ селекції, лабораторія вихідного матеріалу), Сумського національного аграрного університету (кафедра біотехнології та фітофармакологіi), Київського національного університету ім. Тараса Шевченка (лабораторія екології та діагностики вірусних захворювань біологічного факультету) 3 метою проведення ідентифікації збудників вірусних хвороб картоплі, розробки і впровадження рекомендацій щодо діагностування вірусних хвороб і шляхів оздоровлення, виявлення перспективного вихідного матеріалу для селекції.

Генетичний потенціал картоплі далеко не вичерпаний. Створюючи нові сорти, важливо надавати особливу увагу екологічному вивченню, виявляти їх придатність до вирощування в різних грунтово-кліматичних зонах, від чого залежатиме їх подальше успішне впровадження у виробництво.

Надалі планується поповнення колекції картоплі шляхом інтродукції та наукового обміну між установами. Вивчення колекційних зразків із подальшим виділенням і передачею джерел господарсько цінних ознак до науково-дослідних установ України з метою включення їх до селекційних програм.

ческое руководство / Л. С. Литвинов - Л. : ВИР, 1988. - $226 \mathrm{c}$.

5. Международный классификатор СЭВ видов картофеля секции Tuberarium (Dun.) Buk. рода Solanum L. - Л., 1984. - 43 c.

6. Методические рекомендации по проведению исследований с картофелем. - К. : УНИИСХ, 1983. $-216 \mathrm{c}$.

7. Методические указания. Выделение исходного материала для селекции картофеля на основе генеалогии. - С.-Пб, 1992. - 105 с.

8. Методичні рекомендації щодо проведення досліджень з картоплею. - Немішаєве, ІК, 2002. - 
$183 \mathrm{c}$.

9. Подгаєцький А. А. Оцінка та використання генофонду картоплі для створення вихідного селекційного матеріалу / А. А. Подгаєцький, І. Д. Когут // Картоплярство. - № 25. - С. 21-26.

10. Подгаеикий A. А. Перспективность межвидовой гибридизации для практической селекции картофеля / А. А. Подгаецкий // Использование мировых генетических ресурсов ВИР в создании сортов картофеля нового поколения: материалы науч.-координац. конф., посвящ. 100-летию со дня рождения академика К. З. Будина. - С.-Пб, 2009. - C. 23-31.

11. Рябчун В.К. Система генетичних ресурсів рослин України / В. К. Рябчун // Генетичні ресурси рослин України. - 2004. - №1. - С. 8-15.

12. Рябчун B. K. Генетичні ресурси рослин та їх роль у селекції / В. К. Рябчун, Р. Л. Богуславський // Теоретичні основі селекції польових культур: Збірник наукових праць. - Харків, IP ім. В. Я. Юр'єва НААНУ, 2007. - С. 363-398.

13. Харченко Ю. В. Досвід насінництва картоплі на Устимівській дослідній станції рослинництва / Ю. В. Харченко, А. В. Чигрин, Р. О. Бондус //
Вісник Полтавської державної аграрної академії. - Полтава, 2008. - № 4 - С. 82-89.

14. Харченко Ю. В. Вивчення стійкості зразків картоплі до біотичних і абіотичних чинників в умовах Устимівської дослідної станції рослинництва / Ю. В. Харченко, А. В. Чигрин, Р. О. Бондус // Вiсник Полтавської державної аграрної академії. 2009. - № 1. - C. 34-42.

15. Харченко Ю. В. Формування та вивчення колекції картоплі на Устимівській дослідній станції рослинництва: аспекти та пріорітети досліджень / Харченко Ю. В., Чигрин А. В., Бондус Р. О. // Генетичні ресурси рослин. - Х., 2009. - № 7. - С. 22-35.

16. Харченко Ю. В. Досвід та здобутки Устимівської дослідної станції рослинництва в картоплярстві / Ю.В.Харченко, В.В.Чигрин, Р. О. Бондус // Вісник центру наукового забезпечення АПВ Харківської області. - Х., 2010. № 10. - C. 115-133.

17. Maxted N., B. V. Ford-Floyd and J. G. Hawkes. Complementary conservation strategies. // Plant Genetic Resources Conservation. - London, Chapman \& Hall, 1997. - P. 15-39. 